\title{
GEREJA DAN KAUM BAPAK: \\ SEBUAH TINJAUAN METODE PENDAMPINGAN KOGNITIF- \\ BEHAVIORAL BAGI KAUM BAPAK DI HKBP PEARAJA
}

\author{
Joni Tambunan dan Artur Lumbantobing \\ Sekolah Tinggi Guru Huria (STGH) HKBP \\ jonitambunan2604@gmail.com \\ lumbantobingarthur@gmail.com
}

\begin{abstract}
Mentoring is an essential method in Pastoral Care Service. Unfortunately, the mentoring method is often neglected by counselors in mentoring services. As a result, the meeting between counselors and counselee didn't lead the counselee to the expected change. This Journal is a literature study and field research on cognitive-behavioral mentoring methods for fathers who rarely attend church on Sunday at HKBP Pearaja, Tarutung.

In this journal, the author critics the importance of reviewing the mentoring method in providing assistance to fathers who attend church rarely. Furthermore, the author tried to show that the cognitivebehavioral mentoring method equip the fathers to be a priesthood, role model, and teacher in Christian families. In addition, through the cognitive-behavioral method, the church can equip the fathers to bring spiritual growth to a better way. With this paper, the author also offers a contextual approach to seek cognitive-behavioral mentoring methods for fathers.
\end{abstract}

Kata kunci: Church, Fathers, Cognitive-Behavioral, Pastoral Care.

\section{PENDAHULUAN}

Pendampingan pastoral sebagai upaya memanusiakan manusia mengandung makna pemberdayaan. Pemberdayaan yang dimaksudkan adalah ketika pendampingan pastoral tidak hanya terbatas kepada membawa orang keluar dari keterpurukan hidup atau masalah yang dihadapinya tetapi juga mengembangkan potensi-potensi yang ada dalam diri seseorang. 
Pemberdayaan ini yang menjadikan seseorang lebih mampu dan berdaya dalam menghadapi krisis dalam kehidupannya. ${ }^{1}$

Pendampingan pastoral merupakan pertolongan yang bukan hanya untuk meringankan penderitaan tetapi juga untuk menyembuhkan dan menumbuhkan. Dalam usaha menolong berbagai upaya dapat dilakukan sehingga konseli dapat mengembangkan kemampuan untuk mengatasi masalah-masalah atau krisis yang dihadapi ${ }^{2}$. Pendampingan pastoral harusnya menyentuh seluruh lapisan masyarakat. Dapat dikatakan, bahwa gereja melalui pelayanan pendampingan pastoral terpanggil untuk memberitakan Injil yang adalah kabar baik bagi segala bangsa (Mrk. 16: 15). Dalam konteks HKBP, pendampingan pastoral harusnya menyentuh seluruh lapisan jemaat, baik anak-anak, remaja, pemuda, kaum ibu dan kaum bapak. Sebagaimana juga ditegaskan oleh Van Beek, bahwa semua orang Kristen adalah domba Allah, maka pendampingan pastoral hendaknya menyentuh semua domba-domba Allah, yakni semua orang Kristen. ${ }^{3}$

Pendampingan pastoral merupakan pelayanan yang sangat penting dilakukan oleh HKBP, sebab jemaat HKBP menghadapi berbagai macam krisis dalam kehidupannya. Jemaat HKBP, khususnya kaum bapak dalam pengamatan saya selalu bersentuhan dengan berbagai krisis yang menggerogoti kehidupannya. Seperti yang telah kita ketahui bersama, krisis ekonomi, kesehatan, moral, spiritual dan lainnya menjadi sesuatu yang tidak dapat dihindari dan sering sekali membelenggu kaum bapak. Selain itu, konflik yang terjadi di tengah keluarga atau pun masyarakat menjadi penyebab banyak kaum bapak yang depresi sehingga memilih untuk menutup diri, memilih untuk tidak terlibat dalam persekutuan di gereja, baik ibadah, penelaahan Alkitab, kegiatan-kegiatan lainnya bagi kaum bapak di gereja.

Pertanyaan yang kemudian akan muncul adalah, siapa yang bertanggung jawab dalam pelayanan pendampingan pastoral bagi kaum bapak di HKBP? Pengakuan Iman HKBP tahun 1951, pasal sembilan tentang pelayan-pelayan gereja juga menegaskan, bahwa tiap-tiap orang Kristen terpanggil menjadi saksi Kristus. Dijelaskan juga bahwa tugas dari pelayan gereja salah satunya untuk menggembalakan anggota jemaat. Senada dengan itu, Pengakuan Iman HKBP tahun 1996 khususnya pada pasal sembilan juga menegaskan, bahwa semua orang Kristen, laki-laki dan perempuan terpanggil untuk menjadi saksi Kristus di dunia ini. Beberapa tugas dalam pelayanan

\footnotetext{
${ }^{1}$ Engel J.D, Pastoral dan Kebutuhan Dasar Konseling (Jakarta: BPK. Gunung Mulia, 2016).1.

${ }^{2}$ Howard Clinebal, Tipe-Tipe Dasar Pendampingan Dan Konseling Pastoral (Yogyakarta: Kanasius, 2002 ).32.

${ }^{3}$ Aart Van Beek, Pendampingan Pastoral (Jakarta: Gunung Mulia, 2012).10.
} 
itu di tengah gereja adalah menggembalakan warga gereja, membebaskan orang dari berbagai kemiskinan dan kebodohan. ${ }^{4}$

Dalam pendampingan pastoral, metode merupakan sesuatu yang sangat esensial. Metode yang berdasar atas kerangka pikir atau teori memungkinkan untuk menjelaskan sebuah peristiwa dengan menentukan serangkaian faktor sederhana atas terjadinya peristiwa, untuk memprediksi dan kemudian mengontrol pendampingan pastoral. Dapat dikatakan, metode yang berdasar atas kerangka pikir dan teori menjadi alat pendekatan, memahami dan kemudian menolong. ${ }^{5}$

Metode pendampingan pastoral juga menolong konselor untuk memberikan respons yang benar atas informasi yang kompleks dari konseli. Metode yang digunakan konselor mendampingi konselinya akan memungkinkan adanya pertumbuhan pada tujuan yang diharapkan. Dengan demikian, metode pendampingan pastoral yang berdasar pada teori merupakan sesuatu yang vital dalam pendampingan pastoral bagi kaum bapak yang mengalami krisis dalam aspek spiritual, termasuk kaum bapak yang jarang beribadah ke gereja pada hari Minggu.

Pendampingan harus terbuka dalam metode-metodenya. Selain itu, harus bersifat transkultural, terbuka terhadap cara-cara yang baru untuk orang miskin dan lemah, golongan etnis minoritas, wanita dan orang-orang dari kebudayaan asing. Metode-metode pendampingan bersifat terbuka, artinya berusaha untuk memahami perspektif orang lain dalam mendampinginya ${ }^{6}$. Krisis kaum bapak di HKBP dalam aspek spiritual terlihat dari kurangnya keterlibatan kaum bapak beribadah ke gereja pada hari Minggu. Pada hari Minggu orang Kristen harusnya berhimpun bersama untuk mendengar dan memperhatikan firman Allah, lalu memuji Allah, bernyanyi, dan berdoa. ${ }^{7}$ Kaum bapak di HKBP diharapkan menjadi teladan yang baik untuk memungkinkan anakanaknya bertumbuh mencintai Tuhan dan melayani-Nya. Dengan kata lain, kaum bapak harus memiliki hubungan yang baik dengan Tuhan baru kemudian mengharapkan anaknya memiliki hubungan yang baik dengan Tuhan.

\footnotetext{
${ }^{4}$ HKBP, Pengakuan Iman HKBP 1951 Dan 1996 (Tarutung: Kantor Pusat HKBP, 2006).42.

5 John McLeod, Pengantar Konseling: Teori Dan Studi Kasus (Jakarta: Kencana, 2008).54.

${ }^{6}$ Clinebal, Tipe-Tipe Dasar Pendampingan Dan Konseling Pastoral.33-34.

${ }^{7}$ Martin Luther, Katekismus Besar (Jakarta: BPK. Gunung Mulia, 2012).44.
} 
Tuhan menahbiskan rumah sebagai lembaga untuk melatih anak-anak bagaimana mereka seharusnya bertindak. Tuhan tidak mengharapkan gereja, Pendeta, sekolah atau agen lainnya. Perkembangan spiritual dimulai di rumah, tidak perduli betapa besarnya usaha gereja atau lembaga lainnya. ${ }^{8}$ Dengan demikian, kaum bapak memainkan peranan penting di tengah keluarga Kristen, salah satunya kaum bapak bertanggung jawab atas perkembangan spiritual dari anggota keluarganya. ${ }^{9}$

Berangkat dari pandangan di atas, penulis melihat HKBP perlu melakukan pendampingan bagi kaum bapak, sebagai bagian dari orangtua yang memiliki tanggung jawab besar dalam keluarga. Pendampingan pastoral bagi kaum bapak di HKBP bukan hanya untuk menolong kaum bapak atas krisisnya dalam aspek spiritual tetapi juga memperlengkapi kaum bapak untuk dapat menjalankan tanggung jawabnya sebagai orangtua di tengah keluarga Kristen. John menekankan, jika keluarga ingin menjalankan kegiatan rohaninya secara serius, diperlukan tekad menggantikan cara-cara lama dan menciptakan cara baru untuk bertumbuh bersama dalam Iman. ${ }^{10}$

Penulis merasa metode pendampingan pastoral sebagai alat pendekatan, untuk memahami dan kemudian menolong kaum bapak perlu dikaji dan ditinjau relevansinya. Dari berbagai macam metode pendekatan pendampingan pastoral, Totok menggolongkan metode pendampingan pastoral dalam tiga kategori. Pertama, psikodinamika yang berorientasi pada dorongan dunia ketidaksadaran dan rekonstruksi kepribadian. Kedua, eksperiensial dan relasional yang berorientasi pada arti bagaimana menjadi manusia secara penuh dan utuh, kebebasan dan tanggung jawab manusia, pilihan manusia, menciptakan nilai dan makna kehidupan, kecemasan, rasa bersalah, kesadaran akan hakikat sebagai makhluk terbatas. Ketiga, behavioral atau tingkah laku yang berorientasi pada tindakan dan latihan untuk mengubah tingkah laku, faktor kognitif yang mempengaruhi tingkah laku, pikiran rasional dan irasional yang mempengaruhi tingkah laku, masalah masa kini, penerimaan diri dan tanggung jawab seseorang untuk mengubah dirinya. ${ }^{11}$

Dalam metode pendampingan pastoral kognitif-behaviora, tingkah laku dilihat sebagai hasil dari proses belajar, atau tidak ditentukan oleh masa lalu. Metode ini memfokuskan perhatian

\footnotetext{
8 JohnM Drescer, Tujuh Kebutuhan Anak (Jakarta: BPK. Gunung Mulia, 2001).121.

${ }^{9}$ HKBP, “Agenda HKBP Bahasa Indonesia” (Percetakan HKBP, 2009), Pematangsiantar.11-12.

${ }^{10}$ Marjorie L Thompson, Keluarga Sebagai Pusat Pembentukan (Jakarta: BPK. Gunung Mulia, 2012).21.

${ }^{11}$ Wiryasaputra, Pengantar Konseling Pastoral.158.
} 
pada tingkah laku yang tampak. Metode ini membuat sasaran dari setiap proses pertolongan sejelas mungkin dan membuat ukuran-ukuran keberhasilan atau perubahan dari proses pendampingan sejelas mungkin. Dalam pendampingan pastoral kognitif-behavioral, penyembuhan terjadi melalui proses pendidikan, pembelajaran, dan pelatihan. ${ }^{12}$

Para penganut metode pendampingan kognitif-behavioral meyakini bahwa masalah psikologis dapat dijelaskan, dan akhirnya dapat ditangani melalui metode ini. Dalam metode kognitif-behavioral konselor dituntut bersifat aktif dan direktif serta berfungsi sebagai guru atau pelatih untuk membantu konseli dalam belajar dan berlatih perilaku yang lebih efektif. Metode kognitif-behavioral juga mengembangkan beberapa teknik lain seperti praktik dalam kehidupan nyata, penguatan perilaku, memberikan contoh, mengontrol perilaku, menghentikan pikiran yang merusak, dan latihan tingkah laku baru. ${ }^{13}$

Menurut penulis, metode pendampingan kognitif-behavioral tepat digunakan untuk menolong kaum bapak dari krisisnya pada aspek spriritual, yaitu jarang ibadah ke gereja pada hari Minggu. Sebagaimana diketahui bersama dan ditekankan teori psikologi kognitif bahwa kognitif turut memengaruhi perilaku manusia. Psikologi kognitif memberikan perhatian pada semua proses pemindahan, pengurangan, pengelaborasian, penyimpanan, perbaikan, dan penggunaan kognitif. Kognitif manusia merupakan sesuatu yang sangat menentukan perilaku manusia. Perilaku manusia dan kognitifnya memiliki hubungan yang erat, dengan kata lain perilaku manusia dipengaruhi oleh pola pikir atau kognitifnya. ${ }^{14}$

\section{METODE KOGNITIF-BEHAVIORAL}

Metode kognitif-behavioral merupakan sebuah pendekatan yang tumbuh dari perkembangan dalam psikologi behavioral dan kognitif. Metode kognitif-behavioral menekankan pendekatan yang memiliki tujuan dan terstruktur, dan menggunakan teknik-teknik tertentu dalam penugasan pekerjaan, latihan relaksasi, monitor diri, dan pencegahan. Metode kognitif-behavioral juga berkonsentrasi pada memotivasi dan pembicaran tentang solusi pada konseli. ${ }^{15}$

\footnotetext{
12 Wiryasaputra, Pengantar Konseling Pastoral.172.

13 Wiryasaputra, Pengantar Konseling Pastoral.173.

${ }^{14}$ Stephen K Read, Kognisi Teori Dan Aplikasi (Jakarta: Salemba Humanika, 2011).2.

${ }^{15}$ McLeod, Pengantar Konseling: Teori Dan Studi Kasus.174-175.
} 


\section{KAUM BAPAK DAN MASALAHNYA}

Persoalan mengenai sedikitnya jumlah kaum bapak yang beribadah di HKBP bukan merupakan persoalan baru yang mungkin disebabkan karena pandemi covid-19 yang sedang melanda dunia. Karena, bahkan sebelum pandemi melanda dunia kehadiran kaum bapak untuk beribadah di gereja pada hari Minggu lebih sedikit dibandingkan dengan jumlah kehadiran remaja laki-laki dan perempuan, pemuda/i, dan kaum ibu yang beribadah ke gereja. Kenyataan yang demikian ternyata juga disadari oleh beberapa jemaat HKBP Pearaja, salah satunya oleh M. Simorangkir saat ditemui di kediamannya.

Kaum bapak ini yang paling susah, bahkan disemua daerah kehadiran kaum bapak untuk beribadah di gereja sangat sedikit. Kaum bapak hanya sedikit lebih menonjol dikegiatan adat Batak, bahkan itu pun sudah mulai berkurang. Bahkan dikegiatan adat pun kaum ibu sudah lebih di depan, permasalahannya kaum bapak masih mempertahankan identitasnya sebagai kepala keluarga, namun dalam segi kemampuan sebenarnya dapat dikatakan tidak mampu lagi. Demikian juga di gereja, kehadiran kaum bapak sudah sangat minim untuk beribadah ke gereja, bahkan di daerah lain yang saya perhatikan, kehadiran kaum bapak untuk beribadah pada hari Minggu di gereja sudah sangat minim. ${ }^{16}$

Dengan demikian, maka dapat dikatakan bahwa persoalan mengenai minimnya kehadiran kaum bapak di gereja bukanlah persoalan baru, dan bahkan mungkin juga dirasakan dan disadari oleh gereja-gereja di daerah lain. Persoalan yang demikian juga dirasakan oleh HKBP Pearaja. Kehadiran kaum bapak di HKBP Pearaja untuk mengikuti ibadah Minggu sangat sedikit, bahkan sebelum masa pandemi covid-19.

Kehadiran kaum bapak sangat minim, baik pada ibadah lingkungan (partangiangan weik) atau pun pada ibadah di gereja pada hari Minggu. Di lingkungan exaudi ini ada sekitar tujuh puluh delapan keluarga, tetapi bisa dihitung dengan jari berapa jumlah kaum bapak yang beribadah ke gereja pada hari Minggu. Kebetulan memang dari statistiknya lebih banyak kaum ibu dari kaum bapak, tetapi dari jumlah kaum bapak itu pun sangat sedikit kaum bapak yang beribadah ke gereja pada hari Minggu. Pada ibadah lingkungan, terkadang hanya kaum bapak yang ada di rumah itu atau yang menjadi tuan rumah yang hadir mengikuti ibadah itu. Tidak jarang juga kaum bapak yang hadir di ibadah lingkungan tersebut hanya pelayan tahbisan, seperti sintua, pendeta, guru jemaat, atau jika ada kaum bapak yang datang dari lingkungan lain. ${ }^{17}$

Kenyataan yang demikian juga disadari oleh pelayan tahbisan penuh waktu yang ada di HKBP Pearaja. Pelayan tahbisan penuh waktu yang ada di HKBP Pearaja menyadari bahwa ada

\footnotetext{
${ }^{16}$ Mual Tarida Simorangkir, Wawancara oleh penulis, (Tarutung, Indonesia, May 3, 2021).

${ }^{17}$ Simorangkir, Wawancara oleh Penulis.
} 
banyak kaum bapak yang jarang beribadah ke gereja. Bahkan, ada kaum bapak yang beribadah ke gereja hingga bertahun-tahun dan bahkan dengan jumlah yang cukup besar.

Kalau ditanya adakah kaum bapak yang jarang beribadah ke gereja, maka itu sudah pasti ada, bahkan cukup banyak jika dibandingkan dengan jumlah jemaat yang ada di HKBP Pearaja. Secara persentasi, lebih banyak jumlah kaum bapak yang malas beribadah ke gereja dari pada yang sering beribadah ke gereja. ${ }^{18}$

Di HKBP Pearaja, sejak zaman dulu memang tidak pernah lebih banyak jumlah kaum bapak yang beribadah ke gereja pada hari Minggu. Tetapi, saya selalu penasaran dan terus belajar apa yang menjadi penyebabnya dan bagaimana mendorongnya supaya jumlah kaum bapak yang beribadah ke gereja pada hari Minggu itu meningkat, bisa mengimbangi jumlah remaja, pemuda, dan kaum ibu. Supaya tidak terlalu timpang jumlah kehadiran kaum bapak tersebut. Tetapi, memang ini persoalan yang sudah lama dan kemungkinan bukan hanya di wilayah Silindung atau di HKBP Pearaja ini jumlah kaum bapak yang beribadah ke gereja pada hari Minggu itu lebih sedikit. ${ }^{19}$

Sedikitnya kehadiran kaum bapak untuk beribadah ke gereja tentunya dipengaruhi oleh banyak faktor. Secara khusus di HKBP Pearaja, ada beberapa faktor penyebab kaum bapak jarang beribadah ke gereja, beberapa faktor penyebab tersebut akan dijelaskan sebagai berikut, yaitu:

\section{1) Ibadah belum menjadi sebuah kebutuhan bagi kaum bapak di HKBP Pearaja.}

Secara umum kaum bapak di HKBP Pearaja belum menyadari bahwa ibadah merupakan sebuah kebutuhan baginya sebagai orang Kristen. Dengan demikian, mereka merasa bahwa ibadah itu bukanlah sesuatu yang penting, maka mereka kemudian muncul sikap tidak perduli akan ibadah bahkan ketika dilakukan di mana pun, baik di gereja, di lingkungan atau di mana pun. Demikian juga ditegaskan oleh Pendeta Saor Hutagaol:

Ada banyak faktor penyebab kaum bapak jarang beribadah ke gereja, tetapi secara umum kaum bapak jarang beribadah ke gereja karena ibadah belum menjadi kebutuhan baginya sebagai orang Kristen. Maka, kaum bapak tidak akan perduli, bahkan di mana pun ibadah itu dilakukan. Ketika kaum bapak menyadari bahwa ibadah merupakan kebutuhannya sebagai orang Kristen, maka dia akan datang. Ketika kaum bapak butuh anaknya untuk dibaptis di gereja, maka dia akan datang. Itu merupakan contoh sederhana, bahwa ketika sesuatu itu menjadi sebuah kebutuhan. Maka, ketika ibadah menjadi sebuah kebutuhan baginya, maka dia akan datang dan beribadah. ${ }^{20}$

\footnotetext{
${ }^{18}$ Saor Hutagol, Wawancara Oleh Penulis (Tarutung, Indonesia, April 26, 2021).

${ }^{19}$ Simorangkir, Wawancara oleh penulis.

${ }^{20}$ Hutagol, Wawancara Oleh Penulis.
} 
Dapat dikatakan, bahwa kaum bapak secara umum di HKBP Pearaja belum merasa bahwa ibadah adalah kebutuhan baginya. Mereka lebih mengandalkan kekuatannya untuk bertahan hidup, seolah tidak percaya bahwa Allah yang memelihara kehidupannya dan mencukupkan segala yang diperlukannya. Dengan kata lain, kaum bapak di HKBP Pearaja merasa nyaman hidup tanpa ada campur tangan Tuhan dalam kehidupannya. Mereka merasa bahwa selama mereka masih punya tenaga untuk bekerja, mereka akan mampu bertahan hidup dan mencukupi kehidupannya tanpa menyadari adanya kuasa Tuhan dalam kehidupannya.

Kami lama hidup di Jakarta, dan menurut saya di sana suami istri itu kompak, maka pada hari Minggu mereka sama-sama pergi beribadah ke gereja dengan seluruh anggota keluarganya. Kalau di HKBP Pearaja, menurut saya mereka masih merasa nyaman hidup tanpa ada campur tangan Tuhan. Mereka merasa bahwa mereka masih punya tenaga, sehingga masih mampu bekerja untuk bertahan hidup. ${ }^{21}$

Kaum bapak di HKBP Pearaja masih kurang menyadari adanya campur tangan Tuhan dalam kehidupan mereka. Secara umum mereka masih hidup dengan mengandalkan kekuatannya dan merasa bahwa dengan kekuatannya mereka masih mampu bekerja dan bertahan hidup. Sementara mereka kurang menyadari adanya kuasa Allah yang memberikan mereka kekuatan, memberikan mereka kesehatan, dan memberkati pekerjaan mereka sehingga segala kebutuhan mereka untuk hidup dapat tercukupi. Dengan demikian mereka merasa nyaman untuk tidak mengucap syukur kepada Allah yang selama ini memelihara kehidupan mereka.

\section{2) Faktor lingkungan.}

Sedikitnya kehadiran kaum bapak untuk beribadah di gereja ternyata juga dipengaruhi oleh faktor dari lingkungannya, salah satunya kurangnya keteladanan dari pelayan tahbisan di gereja dan jemaat yang sering beribadah ke gereja.

Orang yang sering bergereja atau bisa kita katakan pelayan tahbisan di gereja belakangan ini tidak lagi menjadi teladan dan panutan bagi jemaat. Mereka melihat bahwa pelayan tahbisan di gereja dan juga jemaat yang sering beribadah ke gereja belum tentu perilakunya lebih baik dari orang yang jarang beribadah ke gereja. Selain itu, pelayan tahbisan gereja belakangan ini sudah kurang melayani atau memberikan perhatian terhadap kaum bapak yang jarang beribadah ke gereja, mungkin karena jemaatnya sudah terlalu banyak. Pelayan tahbisan di gereja mungkin merasa bahwa jemaat sudah sangat banyak, maka ketika ada kaum bapak yang tidak beribadah ke gereja pada hari Minggu bukan menjadi suatu masalah, sebab gereja sudah penuh sehingga kaum bapak yang tidak beribadah ke gereja pada hari Minggu tidak

${ }^{21}$ B. Lumbantobing, Wawancara Oleh Penulis (Tarutung, Indonesia, May 4, 2021). 
lagi disentuh. Pelayanan di HKBP Pearaja hanya terbatas pada mengunjungi orang yang sakit, itu pun yang sudah dirawat di rumah sakit terlebih dahulu. ${ }^{22}$

Kegagalan dari para pelayan tahbisan di gereja dan juga jemaat yang sering beribadah ke gereja dijadikan alasan oleh kaum bapak untuk tidak beribadah ke gereja. Mereka kemudian membandingkan kehidupannya dengan para pelayan tahbisan di gereja dan juga jemaat yang sering beribadah ke gereja, dan kemudian merasa bahwa kehidupannya tidak jauh lebih buruk meskipun tidak beribadah ke gereja. Tidak hanya itu, tidak jarang juga mereka merasa bahwa kehidupannya jauh lebih baik dari orang-orang yang sering beribadah ke gereja pada hari Minggu itu.

Sebagian kaum bapak membandingkan kehidupannya dengan orang-orang di lingkungannya yang sering beribadah ke gereja. Terkadang mereka merasa kehidupannya lebih baik, karena mereka melihat jemaat yang sering beribadah ke gereja itu berkelahi, mencuri, berbohong, dan hal-hal negatif lainnya. Jadi, mereka membandingkan itu, dan kemudian merasa bahwa mereka baik-baik saja walau tidak beribadah ke gereja, karena yang beribadah ke gereja pun kehidupannya tidak jauh berbeda dengan mereka. ${ }^{23}$

Kehidupan pelayan tahbisan di gereja dan jemaat yang sering beribadah ke gereja pada hari Minggu sering sekali dijadikan perbandingan dan kemudian menjadi alasan bagi kaum bapak untuk tidak beribadah ke gereja pada hari Minggu. Berdasarkan penelitian yang dilakukan, meskipun bukan faktor penyebab utama, tetapi ini merupakan salah satu faktor penyebab yang kuat atau alasan kuat bagi kaum bapak untuk tidak beribadah ke gereja pada hari Minggu.

Ada orang yang rajin beribadah ke gereja pada hari Minggu, dan ada orang yang jarang beribadah ke gereja pada hari Minggu, tetapi dalam kehidupan sehari-hari lebih baik orang yang tidak beribadah ke gereja ini. Orang yang jarang beribadah ke gereja pada hari Minggu ini terkadang lebih mengasihi saudaranya, tidak mau berkelahi, tetapi yang sering beribadah ke gereja pada hari Minggu ini sering berkelahi. Mereka menjadikan ini alasan dan membenarkan tindakannya yang tidak beribadah ke gereja pada hari Minggu. Dalam dirinya, Imannya tidak bertumbuh, maka tidak ada aplikasinya dalam kehidupan sehari-hari. Tetapi, jemaat yang jarang beribadah ke gereja, terkadang dia hanya tahu sedikit tentang Firman yang mengatakan kasihilah sesamamu seperti dirimu tetapi mampu mengaplikan dalam kehidupannya walau pun dia tidak beribadah ke gereja pada hari Minggu. ${ }^{24}$

Tidak hanya itu, selain dari faktor kurangnya keteladanan dari pelayan tahbisan di gereja dan jemaat yang sering beribadah ke gereja pada hari Minggu, orang tua di lingkungan sekitar juga

\footnotetext{
22 Lumbantobing, Wawancara oleh penulis .

${ }^{23}$ Mei Tobing, Wawancara Oleh Penulis (Tarutung, Indonesia, May 3, 2021).

${ }^{24}$ Simorangkir, Wawancara oleh penulis.
} 
tidak lagi mampu mengarahkan generasi muda yang ada di sekitarnya. Orang yang lebih tua tidak lagi mau menegur, mengarahkan, dan mengajak generasi muda yang jarang beribadah ke gereja pada hari Minggu, bahkan tidak jarang memberikan contoh yang tidak baik seperti duduk di kedai tuak (lapo tuak) pada hari Minggu saat ibadah Minggu berlangsung di HKBP Pearaja.

Semasa kecil, saya kalau tidak beribadah ke gereja pada hari Minggu tidak akan berani keluar rumah. Jangankan untuk duduk di lapo tuak untuk keluar rumah pun saya tidak berani, karena pasti akan ditanya oleh orang-orang yang lebih tua, ditanya teman-teman. Orang-orang di sekitar saya dahulu kalau melihat saya tidak beribadah ke gereja pada hari Minggu, tidak segan-segan untuk menegur saya, bahkan ke semua orang bukan hanya saya. Tetapi, sekarang tidak ada lagi demikian, bahkan setelah saya menjadi sintua, ketika saya mengingatkan jemaat untuk beribadah pada hari Minggu, tidak lagi diindahkan. ${ }^{25}$

Satu sisi, peran orang yang lebih tua dulunya sangat menonjol untuk mengarahkan jemaat, termasuk kaum bapak yang tidak beribadah ke gereja pada hari Minggu. Hubungan kekeluargaan masih sangat erat, mereka masih merasa bahwa mereka masih bagian dari satu keluarga besar yang perlu saling mengingatkan. Belakangan ini, budaya yang demikian sudah tidak terlihat lagi di tengah-tengah jemaat HKBP Pearaja. Pada sisi yang lain, generasi muda sudah kurang menaruh rasa hormat terhadap orang yang lebih tua. Dengan demikian, lingkungan sebenarnya memberikan pengaruh yang besar sehingga dapat dikatakan salah satu faktor penyebab kaum bapak di HKBP Pearaja jarang beribadah ke gereja pada hari Minggu.

\section{3) Kaum bapak di HKBP Pearaja merasa bahwa ibadah tidak memberikan keuntungan.}

Secara umum kaum bapak di HKBP Pearaja terpaku pada pemahaman untung dan rugi. Keuntungan yang dipahami kaum bapak hanya dalam bentuk materi. Maka, kehadiran kaum bapak untuk beribadah ke gereja pada hari Minggu dipengaruhi oleh pemahaman mereka akan keuntungan. Mereka merasa tidak mendapatkan keuntungan apa pun ketika beribadah ke gereja pada hari Minggu. Dengan demikian, mereka kemudian memilih untuk tidak beribadah ke gereja pada hari Minggu, dan memilih mengerjakan sesuatu yang lain yang memberikan keuntungan baginya.

Kaum bapak yang tidak perduli itu, merasa tidak ada yang bisa dia dapat dari gereja. Mereka berpikiran bahwa tidak ada yang bisa dia peroleh, dalam arti materi. Mereka melihat bahwa gereja memberikan kerugian karena gereja meminta, bahkan menguras apa yang ada dari mereka. Bahkan ada banyak dari kaum bapak yang jarang beribadah ke gereja ini yang

\footnotetext{
${ }^{25}$ Simorangkir, Wawancara oleh penulis .
} 
mengkritik ketika ada pengumpulan dana di gereja, seperti gugu toktokripe, sumbangan bersama, persembahan tahunan, dan lain sebagainya. Karena dia merasa bahwa tidak ada yang dia dapat dari gereja, maka dia tidak ke gereja. ${ }^{26}$

Ketika kaum bapak merasa mendapatkan keuntungan dari gereja, maka mereka akan berlomba-lomba untuk datang ke gereja. Pemahaman yang demikian juga menjadi salah satu faktor yang memengaruhi kehadiran kaum bapak beribadah ke gereja pada hari Minggu di HKBP Pearaja.

\section{4) Faktor sosial.}

Kehadiran kaum bapak untuk beribadah ke gereja pada hari Minggu juga dipengaruhi oleh faktor sosial, seperti hubungan mereka dengan jemaat yang lain bahkan terhadap pelayan gereja.

Faktor yang juga memengaruhi kehadiran kaum bapak untuk beribadah pada hari Minggu di gereja adalah sosial, atau hubungan mereka dengan jemaat lainnya atau pun terhadap pelayan gereja. Mereka memiliki hubungan sosial yang tidak baik dengan pelayan di gereja, kemudian mereka memilih untuk tidak beribadah ke gereja. Sebelumnya dia rajin datang dan beribadah ke gereja pada hari Minggu, tetapi karena tidak suka terhadap pelayan kemudian memilih untuk tidak datang lagi ke gereja. ${ }^{27}$

Ada juga memang kaum bapak rajin ke gereja karena ada komunitasnya, seperti kelompok paduan suara yang mana dia sendiri terlibat di dalamnya. Kalau dia ikut dalam komunitas itu, maka dia akan rajin datang ke gereja. ${ }^{28}$

Persoalan sosial kaum bapak juga berdampak terhadap jumlah kehadiran kaum bapak untuk beribadah pada hari Minggu di gereja. Ketika kaum bapak tersebut memiliki hubungan sosial yang baik, dia akan merasa nyaman untuk datang dan beribadah ke gereja pada hari Minggu. Ketika kaum bapak memiliki hubungan yang baik dalam komunitas kecil, seperti kelompok paduan suara, maka dia akan lebih rajin untuk datang dan beribadah ke gereja pada hari Minggu.

Empat faktor yang sudah dijelaskan di atas, merupakan masalah bagi kaum bapak serta faktor penyebab kaum bapak jarang beribadah ke gereja di HKBP Pearaja. Menurut penulis, secara umum keempat faktor tersebut dipengaruhi oleh kognitif dari kaum bapak.

\footnotetext{
${ }^{26}$ Hutagol, Wawancara Oleh Penulis.

27 Hutagaol, Wawancara oleh penulis.

${ }^{28}$ Hutagaol, Wawancara oleh penulis.
} 


\section{PENERAPAN METODE PENDAMPINGAN KOGNITIF-BEHAVIORAL BAGI KAUM BAPAK DI HKBP PEARAJA}

Substansi dari metode pendampingan kognitif-behavioral adalah bahwa tingkah laku merupakan hasil dari proses belajar. Selain itu, perubahan tingkah laku dapat dilakukan dengan proses menirukan, penguatan terhadap rangsangan yang sesuai dengan perubahan yang diharapkan. Beberapa hal mendasar yang penting berdasarkan teori ini adalah proses pendidikan, pembelajaran, dan pelatihan. Dengan demikian, akan terbuka kemungkinan perubahan tingkah laku ke arah yang diharapkan. Dalam menerapkan metode pendampingan kognitif-behavioral bagi kaum bapak yang jarang beribadah ke gereja, perlu menggunakan pendekatan yang sesuai dengan konteks kaum bapak di HKBP Pearaja. Berdasarkan penelitian yang telah dilakukan penulis, beberapa pendekatan yang dapat digunakan dalam menerapkan metode pendampingan kognitif-behavioral adalah sebagai berikut, yaitu:

\section{1) Pendekatan kultural.}

Berdasarkan konteks di HKBP Pearaja, pendekatan kultural dapat digunakan bagi kaum bapak dalam menerapkan metode pendampingan kognitif-behavioral. Seperti yang telah diketahui bersama, bahwa kaum bapak di gereja HKBP Pearaja secara umum merupakan keturunan dari orang Batak toba yang memiliki marga. Salah satu pendekatan kultural untuk dapat menerapkan metode pendampingan kognitif-behavioral yang dapat dilakukan adalah dengan marga.

Pendekatan kultural dapat dipakai untuk melakukan pendidikan, pembelajaran, pelatihan, atau mengedukasi kaum bapak yang jarang beribadah ke gereja pada hari Minggu. Pendekatan kultural yang dapat kita lakukan melalui marga, contohnya adanya keterkaitan marga. Dengan demikian kita bisa membuat mereka lebih dekat kepada kita, tidak ada batasan-batasan, contohnya saya pendeta dan dia jemaat biasa. Pendekatan kultural ini bisa merobohkan tembok-tembok yang memisahkan, dan membuat kita lebih dekat dengan kaum bapak yang jarang beribadah ke gereja. ${ }^{29}$

Dengan pendekatan melalui marga jarak yang sebelumnya cukup jauh antara konselor dan konseli akan dapat teratasi, terlebih ketika konselor dan konseli memiliki hubungan marga. Dengan demikian konseli akan merasa bahwa konselor adalah bagian dari keluarganya, baik itu dongan tubu, hula-hula, boru atau lain sebagainya. Setelah konselor dan konseli memiliki hubungan baik, kemungkinan untuk menerapkan metode pendampingan kognitif-behavioral akan lebih besar.

\footnotetext{
${ }^{29}$ Hutagaol, Wawancara oleh penulis.
} 
Akan lebih besar kemungkinan untuk melakukan pendidikan, pembelajaran, pelatihan, menirukan, dan menguatkan rangsangan yang sesuai dengan perubahan tingkah laku yang diharapkan.

\section{2) Pendekatan kunjungan variatif.}

Pendekatan dengan melakukan kunjungan variatif adalah dengan menemui kaum bapak yang jarang beribadah ke gereja itu di tempat-tempat kesenangan mereka masing-masing. Pendekatan ini sama seperti pendekatan personal, namun dalam pendekata variatif ini konselor ditantang untuk berani menemui konselinya di tempat-tempat kesenangan mereka, atau tempat di mana mereka sering menghabiskan waktu. Dalam konteks HKBP Pearaja, kaum bapak yang jarang beribadah ke gereja secara umum lebih banyak menghabiskan waktunya di kedai tuak (lapo tuak). Karena itu, dalam pendekatan kunjungan variatif ini, konseli menemui kaum bapak yang jarang beribadah ke kedai tuak, bahkan ke tempat-tempat lain di mana mereka berada.

Kunjungan variatif merupakan suatu pendekatan yang dapat dilakukan dalam menerapkan metode pendampingan kognitif-behavioral. Seperti menemui mereka di lapo tuak atau ke tempat di mana dia sering menghabiskan waktunya. Kita buat perjumpaat yang tidak terlalu formal atau kunjungan variatif. Di sana kita bisa berbincang dengan dia dan mencari informasi mengapa dia tidak beribadah ke gereja pada hari Minggu. Dengan perjumpaan yang tidak terlalu formal, maka akan lebih muda kita melakukan pendampingan kepadanya. Kita harus menggunakan banyak pendekatan untuk bisa mendampingi dia, salah satunya adalah kunjungan variatif atau kunjungan ke tempat dia sering menghabiskan waktunya. ${ }^{30}$

Dalam pendekatan ini, konselor memanfaatkan waktu pertemuan tersebut untuk menggali apa yang sebenarnya terjadi, dan penyebab dia (bapak yang jarang beribadah ke gereja pada hari Minggu) jarang beribadah ke gereja pada hari Minggu. Dalam perjumpaan ini juga konselor mulai menerapkan metode pendekatan kognitif-behavioral kepadanya, dengan mengedukasinya, menguatkan rangsangan yang muncul yang sesuai dengan arah perubahan yang diharapkan, dan tentunya melalui percakapan-percakapan ringan yang tidak formal.

\section{3) Pendekatan melalui keluarga.}

Keluarga dapat menjadi sarana pendekatan bagi kaum bapak yang jarang beribadah ke gereja pada hari Minggu. Sebagian kaum bapak sulit ditemui di luar rumah, mereka lebih memilih mengurung diri di rumah. Tidak jarang juga mereka enggan untuk bertemu dengan pelayan tahbisan yang datang dari gereja ketika ingin menemuinya. Untuk dapat bertemu dengan kaum

\footnotetext{
${ }^{30}$ Hutagaol, Wawancara oleh penulis.
} 
bapak yang demikian dapat dilakukan dengan mendekati anggota keluarganya, salah satunya anaknya. Contoh kecilnya, dengan mengantar anaknya ke rumah ketika sudah selesai mengikuti ibadah anak sekolah Minggu di gereja.

Pendekatan yang pernah saya lakukan bagi kaum bapak yang jarang beribadah ke gereja pada hari Minggu adalah pendekatan melalui anaknya. Saya mencari informasi apa kegiatan orang tuanya, apa yang dilakukan orang tuanya pada hari Minggu, dan informasi lainnya. Jadi, saya menyempatkan untuk mengantarkan anaknya ke rumahnya untuk dapat bertemu dengan bapaknya yang jarang beribadah ke gereja pada hari Minggu. Melalui pertemuan yang seperti itu saya melakukan pendekatan kepada bapaknya sembari melakukan pendampingan yang berkelanjutan. Kebanyakan yang saya temukan, pada pertemuan yang seperti itu bapaknya tidak bisa lagi menghindar, dan kemudian mau menyampaikan alasannya kenapa selama ini tidak datang beribadah ke gereja pada hari Minggu. Semakin sering kita datang maka akan semakin baik hubungan kita dengan keluarganya dan juga dengan kaum bapak yang jarang beribadah ke gereja itu, dan disitulah kita dapat melakukan pendampingan pastoral bagi bapaknya yang jarang beribadah ke gereja pada hari Minggu itu. ${ }^{31}$

Keluarga juga dapat dipakai sebagai jalan untuk mendekati kaum bapak yang jarang beribadah ke gereja pada hari Minggu, dan kemudian menerapkan metode pendampingan kognitifbehavioral. Sebagai mana sudah disampaikan di atas, biasanya mereka akan merasa enggan untuk bertemu dengan pelayan tahbisan yang datang dari gereja untuk menemuinya. Maka, ketika sudah ada pertemuan pertama melalui pendekatan keluarga, maka ada kemungkinan untuk lebih mudah bertemu dengannya dan kemudian melakukan pendidikan, pengajaran, pelatihan, penguatan terhadap rangsangan ke arah perubahan yang diharapkan, sehingga sejalan dengan itu ada kemungkinan mereka akan menunjukkan perubahan tingkah laku sesuai dengan yang diharapkan.

\section{4) Pendekatan melalui kebutuhan.}

Di HKBP Pearaja terdapat kaum bapak yang tidak pernah beribadah ke gereja hingga bertahun-tahun. Tidak hanya itu, pelayan tahbisan di HKBP Pearaja pun sangat sulit untuk menemuinya guna melakukan pendampingan pastoral. Mereka hanya akan datang ke gereja ketika memiliki kebutuhan, seperti kebutuhan agar anaknya dibaptis, ketika anaknya hendak menyaksikan Iman, kebutuhan akan surat-surat dari gereja. Dengan kata lain, mereka hanya akan datang ke gereja ketika mereka membutuhkan sesuatu dari gereja. Untuk menerapkan metode pendampingan kognitif-behavioral bagi kaum bapak yang seperti ini, dapat dilakukan melalui kebutuhannya.

Kita dapat melakukan pendampingan pastoral bagi kaum bapak yang jarang beribadah ke gereja melalui kebutuhannya. Contohnya, ketika anaknya perlu dibaptis di gereja. Kita dapat

${ }^{31}$ Ertile Sianturi, Wawancara Oleh Penulis (Tarutung, Indonesia, April 26, 2021). 
menegur mereka, mengajari mereka, mengingatkan mereka, tetapi dengan percakapan yang santai. Kita mencari tau apa yang menjadi alasan tidak beribadah ke gereja selama ini. Ketika dia memiliki kebutuhan dari gereja, maka dia akan datang dengan sendirinya. Ketika dia datang karena kebutuhannya, pada saat itu juga dapat melakukan pendampingan pastoral kepada dia. ${ }^{32}$

Ketika mereka membutuhkan sesuatu dari gereja, itu menjadi jalan masuk untuk melakukan pendampingan pastoral kepadanya. Ketika itulah dapat diterapkan metode pendampingan kognitifbehavioral, melalui pertemuan yang tidak terlalu formal dilakukan pendidikan, pembelajaran, penguatan terhadap rangsangan yang sesuai dengan arah perubahan yang diharapkan.

Beberapa pendekatan yang sudah dijelaskan di atas, dapat menjadi sarana dalam menerapkan metode pendampingan kognitif-behavioral bagi kaum bapak yang jarang beribadah ke gereja pada hari Minggu di HKBP Pearaja.

\section{KESIMPULAN}

Berdasarkan hasil penelitian dan pembahasan yang telah diuraikan di atas dinaytakan bahwa metode pendampingan kognitif-behavioral tepat digunakan untuk mengubah tingkah laku kaum bapak yang jarang beribadah ke gereja pada hari Minggu. Berdasarkan penelitian dan pengamatan saat menerapkan metode pendampingan kognitif-behavioral, terlihat adanya indikasi perubahan tingkah laku dari konseli, walaupun belum sesuai dengan yang diharapkan. Tidak menutup kemungkinan perubahan tingkah laku akan sesuai dengan arah perubahan yang diharapkan jika pendampingan dilakukan secara berkepanjangan dan teratur.

Metode pendampingan kognitif-behavioral juga memperlengkapi kaum bapak menjadi imam, teladan, dan pengajar di tengah keluarga Kristen. Dengan metode pendampingan yang menekankan pendidikan, pengajaran, dan pelatihan gereja dapat memperlengkapi kaum bapak membawa pertumbuhan spiritualitas ke arah yang lebih baik.

\footnotetext{
${ }^{32}$ Lamsiharma Hutagalung, Wawancara Oleh Penulis (Tarutung, Indonesia, April 26, 2021).
} 


\section{DAFTAR PUSTAKA}

\section{BUKU}

Beek, Aart Van. Pendampingan Pastoral. Jakarta: Gunung Mulia, 2012.

Clinebal, Howard. Tipe-Tipe Dasar Pendampingan Dan Konseling Pastoral. Yogyakarta: Kanasius, 2002.

Drescer, JohnM. Tujuh Kebutuhan Anak. Jakarta: BPK. Gunung Mulia, 2001.

HKBP. “Agenda HKBP Bahasa Indonesia.” Percetakan HKBP, 2009. Pematangsiantar.

—. Pengakuan Iman HKBP 1951 Dan 1996. Tarutung: Kantor Pusat HKBP, 2006.

J.D, Engel. Pastoral dan Kebutuhan Dasar Konseling. Jakarta: BPK. Gunung Mulia, 2016.

Luther, Martin. Katekismus Besar. Jakarta: BPK. Gunung Mulia, 2012.

Manuntung, Alfeus. Terapi Perilaku Kognitif Pada Pasien Hipertensi. Malang: Wineka Media, 2018.

McLeod, John. Pengantar Konseling: Teori Dan Studi Kasus. Jakarta: Kencana, 2008.

Read, Stephen K. Kognisi Teori Dan Aplikasi. Jakarta: Salemba Humanika, 2011.

Thompson, Marjorie L. Keluarga Sebagai Pusat Pembentukan. Jakarta: BPK. Gunung Mulia, 2012.

Wiryasaputra, Totok S. Pengantar Konseling Pastoral. Yogyakarta: Diandra Pustaka Indonesia, 2014.

\section{WAWANCARA}

Hutagalung, Lamsiharma. Wawancara Oleh Penulis. Tarutung, Indonesia, April 26, 2021.

Hutagol, Saor. Wawancara Oleh Penulis. Tarutung, Indonesia, April 26, 2021.

Lumbantobing, B. Wawancara Oleh Penulis. Tarutung, Indonesia, May 4, 2021.

Sianturi, Ertile. Wawancara Oleh Penulis. Tarutung, Indonesia, April 26, 2021.

Simorangkir, Mual Tarida. Wawancara oleh penulis. Wawancara. Tarutung, Indonesia, May 3, 2021. 
Tobing, Mei. Wawancara Oleh Penulis. Tarutung, Indonesia, May 3, 2021. 